\title{
Article \\ Effective Propagation of Selaginella tamariscina through Optimized Medium Composition
}

\author{
Kyungtae Park ${ }^{1,2}$, Bo Kook Jang ${ }^{1,2}\left(\mathbb{D}\right.$, Ha Min Lee ${ }^{1,2}$, Ju Sung Cho ${ }^{1,2}$ and Cheol Hee Lee ${ }^{1,2, *(D)}$ \\ 1 Division of Animal, Horticultural and Food Sciences, Chungbuk National University, \\ Cheongju 28644, Korea; pkt4418@naver.com (K.P.); jangbk@chungbuk.ac.kr (B.K.J.); \\ hamin0627@naver.com (H.M.L.); jsc@chungbuk.ac.kr (J.S.C.) \\ 2 Brain Korea 21 Center for Bio-Health Industry, Chungbuk National University, Cheongju 28644, Korea \\ * Correspondence: leech@chungbuk.ac.kr
}

check for updates

Citation: Park, K.; Jang, B.K.; Lee, H.M.; Cho, J.S.; Lee, C.H. Effective Propagation of Selaginella tamariscina through Optimized Medium Composition. Agronomy 2021, 11, 578 https://doi.org/10.3390/ agronomy 11030578

Academic Editor: Matteo Caser

Received: 15 February 2021

Accepted: 17 March 2021

Published: 19 March 2021

Publisher's Note: MDPI stays neutral with regard to jurisdictional claims in published maps and institutional affiliations.

Copyright: (c) 2021 by the authors. Licensee MDPI, Basel, Switzerland. This article is an open access article distributed under the terms and conditions of the Creative Commons Attribution (CC BY) license (https:// creativecommons.org/licenses/by/ $4.0 /)$.

\begin{abstract}
Selaginella tamariscina is a medicinal plant that contains a variety of plant secondary metabolites; however, it is currently being collected indiscriminately from its native habitats. Hence, we have developed an efficient propagation method for $S$. tamariscina. Explants grown in vitro were cultured in Murashige and Skoog medium of various strengths (1/16-2x), and the highest number of sporophytes (65.7) were obtained with 1/4x MS medium. Culturing explants at various lengths (3-12 mm) for 12 weeks indicated $12 \mathrm{~mm}$ as the most appropriate size for sporophyte propagation. We then evaluated various concentrations of individual components, sucrose $(0-5 \%)$, total nitrogen (7.5-30 mM), nitrogen ratio (3:0-0:3), and agar (0.6-0.8\%), in the 1/4x MS medium for explant growth for 12 weeks. The maximum number of sporophytes were formed in media containing $3 \%$ sucrose, $15 \mathrm{mM}$ nitrogen, and $0.6 \%$ agar, with a nitrogen ratio of $1: 2$. The propagated $\mathrm{S}$. tamariscina was then acclimatized in a controlled environment to improve survival in an external environment. These results demonstrate the effective conditions for in vitro mass propagation of S. tamariscina, finding that methods utilizing sporophytes were more efficient than conventional propagation methods and yielded numerous plants in a short period.
\end{abstract}

Keywords: amentoflavone; heterosporous; in vitro; lycophytes; medicinal plant; sporophyte

\section{Introduction}

Selaginella is a representative medicinal fern that contains large amounts of beneficial compounds and various natural substances, such as alkaloids, phenols, and terpenoids [1]. Ginkgetin, a biflavonoid extracted from Selaginella moellendorffii, induces apoptosis in cancer cells and exhibits anticancer effects [2,3]. Biflavonoids extracted from Selaginella willdenowii and Selaginella delicatula effectively inhibit tumor cell growth [4,5]. Additionally, various components and functions have been reported in many Selaginella species [6-14]. Selaginella tamariscina (P.Beauv.) Spring has long been used as a folk remedy in Korea for maintaining hemostasis and improving blood circulation, menstrual irregularity, dysmenorrhea, contusions, and extravasated blood [15]. Active ingredients include amentoflavone, apigenin, hinokiflavone, isocryptomerin, sumaflavone, robustaflavone, and tannin, which show efficacy in treating throat, lung, cervical, mammary, skin, kidney, gastric, rectal, and liver cancers [16-19].

S. tamariscina is a plant of high medicinal value; however, a systematic method of its propagation has not yet been developed. Most $S$. tamariscina currently in circulation is collected indiscriminately from native habitats, which is concerning as such practices disturb the habitat and may lead to a decline in natural populations. Leaf cutting, as a conventional propagation method, often fails to produce outcomes in large quantities because of low propagation efficiency and vulnerability to environmental changes. Therefore, a stable supply of plants to meet increasing demand is essential, and the development of efficient propagation methods is necessary. 
In vitro culture can produce homogeneous plants throughout the year in a controlled environment and promote their rapid propagation [20,21]. Additionally, this method can be used for species conservation and for propagating plants that are difficult to reproduce naturally [22]. However, there have been limited applications of in vitro culture for S. tamariscina reproduction, and further research is needed.

Our experiment involved proliferating the new whole plants in vitro using the sporophytes of S. tamariscina. We have sought the optimal conditions for the proliferation by adjusting various substances forming the medium. Our proliferation method developed in this study will be an efficient system that can provide a stable supply of S. tamariscina, a high-value-added industrial crop. Furthermore, this in vitro culture system is also considered effective in generating useful functional substances of $S$. tamariscina, such as amentoflavone, hinokiflavone, selaginellin, etc. [23-25]. Moreover, this method not only could be utilized as a tool to protect plants from indiscriminate collection in their natural habitats but also as a tool to preserve the plant's habitat, and this indicates the importance of this research for preservation purposes.

\section{Materials and Methods}

\subsection{Plants}

S. tamariscina was grown in a glass greenhouse $\left(36^{\circ} 37^{\prime} 49.6^{\prime \prime} \mathrm{N}, 127^{\circ} 27^{\prime} 05.8^{\prime \prime} \mathrm{E}\right)$ at Chungbuk National University (Cheongju, Korea). After collecting sporophytes of S. tamariscina, the surface was washed with distilled water and sterilized in $70 \%$ ethanol for $1 \mathrm{~min}$, followed by treatment with $2 \%$ sodium hypochlorite for $15 \mathrm{~min}$ and 5 washes with sterile water to remove the residual disinfectant solution. Sporophyte was then cut into 10-mm-long pieces and cultured in MS (Murashige and Skoog) medium [26]. The regenerated plants were sub-cultured at 4-week intervals and used in the experiments.

\subsection{Basal Medium and Explant Length for Effective Propagation}

To select an effective medium to establish an in vitro culture of $S$. tamariscina, we prepared MS media with a range of concentrations of each ingredient: 1/16-, 1/8-, 1/4-, $1 / 2-, 1-$, and 2 -fold. A shoot tip (10 $\mathrm{mm})$ was cultured in each medium, and the set of additive concentrations resulting in optimal growth was selected to formulate the basal medium. To select the optimal fragment length effective for mass propagation, shoot tips were cut to various lengths $(3,6$, and $12 \mathrm{~mm})$ from the apical and cultured for 12 weeks in basal medium. The selected length was then used in subsequent experiments.

\subsection{Assessment of the Effect of Various Medium Components on Propagation and Growth}

Various components were adjusted in the basal medium to determine their role in propagation. Sucrose was adjusted to $0 \%, 1 \%, 2 \%, 3 \%, 4 \%$, and $5 \%$. Agar concentration was adjusted to $0.6 \%, 0.8 \%$, and $1.0 \%$. The total concentration of nitrogen was adjusted to $0.5-, 1-$, and 2-fold of the concentration in the basal medium. The ratio of $\mathrm{NH}_{4}{ }^{+}$to $\mathrm{NO}_{3}{ }^{-}$ was adjusted to 3:0, 2:1, 1:1, 1:2, and 0:3 to determine the optimal nitrogen concentration. Uncontrolled components were established at $15 \mathrm{mM}$ nitrogen, $3 \%$ sucrose, $0.8 \%$ agar, and $\mathrm{pH} 5.8$ for each experiment. Each medium used in the experiments was dispensed at $50 \mathrm{~mL}$ into a $\varnothing 120 \times$ H 80 mm culture vessel (cat. No. 310120; SPL Life Sciences, Pocheon, Korea) and exposed to following culture conditions: temperature, $25 \pm 1.0^{\circ} \mathrm{C}$; light intensity, $30 \pm 1.0$ PPFD $\left(\mu \mathrm{mol} \mathrm{m}^{-2} \mathrm{~s}^{-1}\right)$; and photoperiod $16 / 8 \mathrm{~h}$. After 12 weeks, the fresh weight and the number of formed sporophytes were examined.

\subsection{Acclimation in a Controlled Environment and Greenhouse}

S. tamariscina propagated in vitro was acclimatized in a controlled environment to improve survival before transfer to a greenhouse. Before transplanting to soil, the culture vessel was left open for $24 \mathrm{~h}$ to allow exposure to external air. Horticultural substrate (Hanareum no. 2; Shinsung Mineral Co., Ltd., Goesan, Korea) was filled into plastic pots (Ø10 cm; Bumnong Co., LTD., Jeongeup, Korea), and the residual medium used for 
S. tamariscina culture was removed with tap water prior to transplantation. The pot was placed in a plastic box $\left(503 \times 335 \times 195 \mathrm{~mm}^{3}\right.$; SPC532 (DP-D); SH Plastic, Gyeongsan, Korea) and covered with a glass plate to increase humidity $(85 \pm 5.0 \%)$. Furthermore, daily overhead irrigation was performed to maintain humidity. The environment was controlled in the growth room and was maintained at $25 \pm 1.0^{\circ} \mathrm{C}$ with a light exposure of $43 \pm 1.0$ PPFD $\left(\mu \mathrm{mol} \mathrm{m}^{-2} \mathrm{~s}^{-1}\right)$ and a photoperiod of $16 / 8 \mathrm{~h}$. S. tamariscina was transferred to the greenhouse after 12 weeks of transplanting. Acclimation was carried out in the greenhouse from August to October with an average temperature of $24 \pm 1.0{ }^{\circ} \mathrm{C}$ and humidity of $46 \pm 1.4 \%$ under natural sunlight with $50 \%$ sunshade.

\subsection{Statistics and Data Analysis}

To measure S. tamariscina growth and propagation, we examined the number of sporophytes formed per explant and the fresh weight. Sporophyte development was observed using a stereomicroscope (SZ61; Olympus, Tokyo, Japan). All experiments were repeated four times, and six explants were used per replicate. The software SAS version 9.4 (SAS Institute Inc., Cary, NC, USA) was used to calculate the mean \pm standard error for each treatment. Factorial analysis was performed using Duncan's multiple range test with significance determined at $p<0.05$.

\section{Results}

\subsection{Determination of Optimal MS Strength for Propagation and Growth}

Sporophytes formed at all medium strengths, except 2MS, where explants exhibited browning and died. Among the MS strengths, 1/4MS resulted in 65.7 sporophytes formed per explant with the highest fresh weight of $221.0 \mathrm{mg}$ (Table 1). Browning of some sporophytes was observed at 1MS, the standard concentration of MS medium, and growth was poor relative to that observed at other strengths. Therefore, $1 / 4 \mathrm{MS}$ was used as the basal medium in subsequent experiments.

Table 1. Effect of medium strength on $10 \mathrm{~mm}$ shoot tip explant of Selaginella tamariscina (P.Beauv.) Spring growth and sporophyte regeneration after 12 weeks of culturing.

\begin{tabular}{ccc}
\hline Medium Strength & No. of Sporophytes/Explant & Fresh Weight/Explant (mg) \\
\hline $1 / 16 \mathrm{MS}$ & $11.2 \pm 1.94 \mathrm{~d}^{*}$ & $22.4 \pm 4.73 \mathrm{~cd}$ \\
$1 / 8 \mathrm{MS}$ & $23.5 \pm 4.18 \mathrm{c}$ & $43.5 \pm 8.44 \mathrm{c}$ \\
$1 / 4 \mathrm{MS}$ & $65.7 \pm 6.64 \mathrm{a}$ & $221.0 \pm 16.55 \mathrm{a}$ \\
$1 / 2 \mathrm{MS}$ & $32.7 \pm 0.63 \mathrm{~b}$ & $139.7 \pm 16.27 \mathrm{~b}$ \\
$1 \mathrm{MS}$ & $8.6 \pm 0.97 \mathrm{~d}$ & $27.1 \pm 3.12 \mathrm{c}$ \\
$2 \mathrm{MS}$ & $0.00 \mathrm{e}$ & $0.9 \pm 0.01 \mathrm{~d}$ \\
\hline
\end{tabular}

* Different letters within columns indicate a significant difference determined via Duncan's multiple range test at $5 \%$ significance.

\subsection{Effective Explant Length for Sporophyte Propagation}

When shoot tips were cut into three lengths and cultured in 1/4MS medium, all explants formed sporophytes, and no significant difference in survival rate was detected among shoot tips of different lengths (Table 2). However, we observed differences in the number of sporophytes formed per explant, with 48.7 sporophytes formed from $12 \mathrm{~mm}$ explants along with a fresh weight of $81.9 \mathrm{mg}$ (Figure 1). In explants of $3 \mathrm{~mm}$ and $6 \mathrm{~mm}$, the numbers of sporophytes were 29.2 and 28.1 per explant, respectively, with similar decreases in fresh weight relative to that of $12 \mathrm{~mm}$ explants. Therefore, we used $12 \mathrm{~mm}$ explants in subsequent experiments. 
Table 2. Effect of explant growth on S. tamariscina (P.Beauv.) Spring growth and sporophyte regeneration after 12 weeks of culturing on $1 / 4$ MS medium.

\begin{tabular}{cccc}
\hline Explant Length $(\mathbf{m m})$ & Survival Rate (\%) & No. of Sporophytes/Explant & Fresh Weight/Explant (mg) \\
\hline 3 & $75.0 \pm 8.33 \mathrm{a}^{*}$ & $29.2 \pm 4.35 \mathrm{~b}$ & $32.4 \pm 4.70 \mathrm{~b}$ \\
6 & $87.5 \pm 7.98 \mathrm{a}$ & $28.1 \pm 1.20 \mathrm{~b}$ & $30.2 \pm 4.00 \mathrm{~b}$ \\
12 & $88.9 \pm 11.11 \mathrm{a}$ & $48.7 \pm 2.22 \mathrm{a}$ & $81.8 \pm 1.49 \mathrm{a}$ \\
\hline
\end{tabular}

* Different letters within columns indicate a significant difference determined via Duncan's multiple range test at 5\% significance.

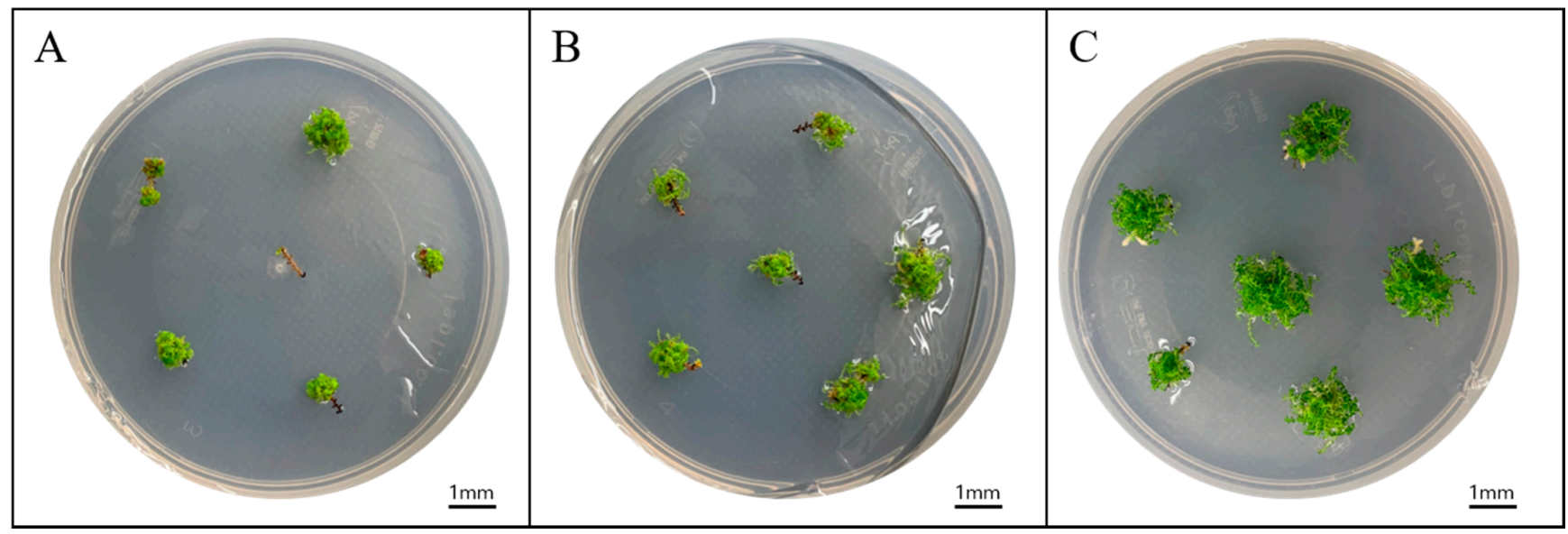

Figure 1. S. tamariscina (P.Beauv.) Spring sporophyte regeneration. Results according to different explant lengths: (A) $3 \mathrm{~mm}$, (B) $6 \mathrm{~mm}$, and (C) $12 \mathrm{~mm}$ after culturing for 12 weeks on 1/4 MS medium.

\subsection{Sporophyte Regeneration According to Sucrose Concentration}

All S. tamariscina explants formed sporophytes in the presence or absence of sucrose in the medium (Figure 2A). In the medium without sucrose, 19.4 sporophytes were formed per explant, and the highest number of regenerated sporophytes was obtained at $3 \%$ sucrose (57.6 sporophytes per explant). Higher sucrose concentrations (4\% and 5\%) resulted in browning of some explants accompanied by browned and poorly grown sporophytes. All concentrations, except 3\%, showed similar phenotypes with no significant difference in characteristics monitored.

\subsection{Effect of Agar Concentration on Growth and Propagation}

Sporophyte regeneration varied according to agar concentration in the medium (Figure 2B). Among the three tested concentrations, the highest number of sporophytes per explant (65.6) was formed at the lowest agar concentration (0.6\%). Additionally, we observed that 30.8 sporophytes formed at $0.8 \%$ agar, and the lowest number of sporophytes formed (10.3) at $1.0 \%$ agar.

\subsection{The Effect of Nitrogen Concentration and $\mathrm{NH}_{4}{ }^{+}: \mathrm{NO}_{3}{ }^{-}$Ratio on Growth and Propagation}

We observed a significant difference in sporophyte growth and regeneration among media with distinct nitrogen concentrations (Figure 2C). The highest number of sporophytes formed (50.7) in medium containing $15 \mathrm{mM}$ nitrogen with the highest fresh weight of $103.1 \mathrm{mg}$. By contrast, 33.5 sporophytes were formed in medium containing $7.5 \mathrm{mM}$ nitrogen, and 10.5 sporophytes were formed at $30 \mathrm{mM}$ nitrogen. We then adjusted the $\mathrm{NH}_{4}{ }^{+}: \mathrm{NO}_{3}{ }^{-}$ratio in medium containing $15 \mathrm{mM}$ nitrogen. We found that sporophytes did not re-differentiate due to explant necrosis at 3:0 and 0:3 (Figure 2D), whereas the highest numbers of sporophytes formed in media at ratios of 1:2 and 1:1 (57.6 and 45.1, respectively). However, the fresh weight was $120.9 \mathrm{mg}$ in medium at a 1:2 ratio, which was higher than that at 1:1. Moreover, sporophytes formed at the 2:1 ratio showed browning tendencies. 
A

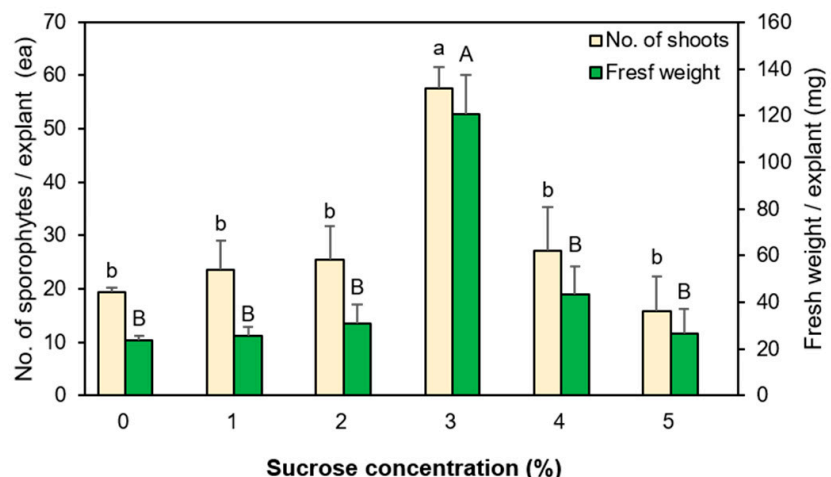

C

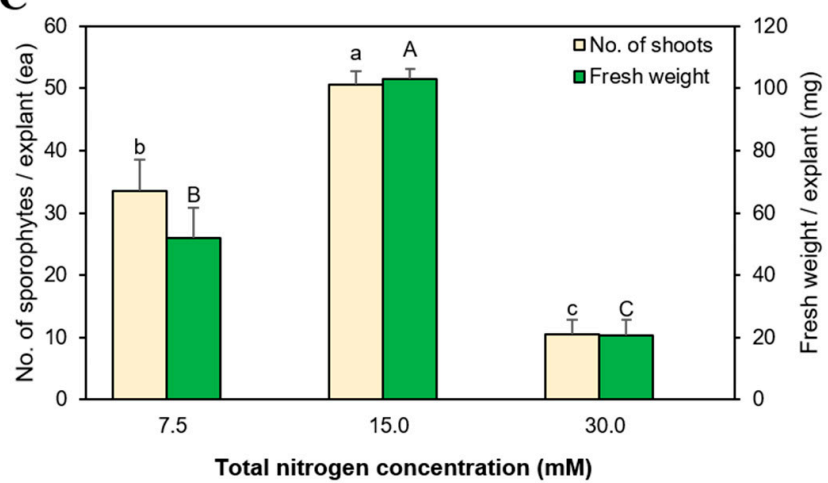

B
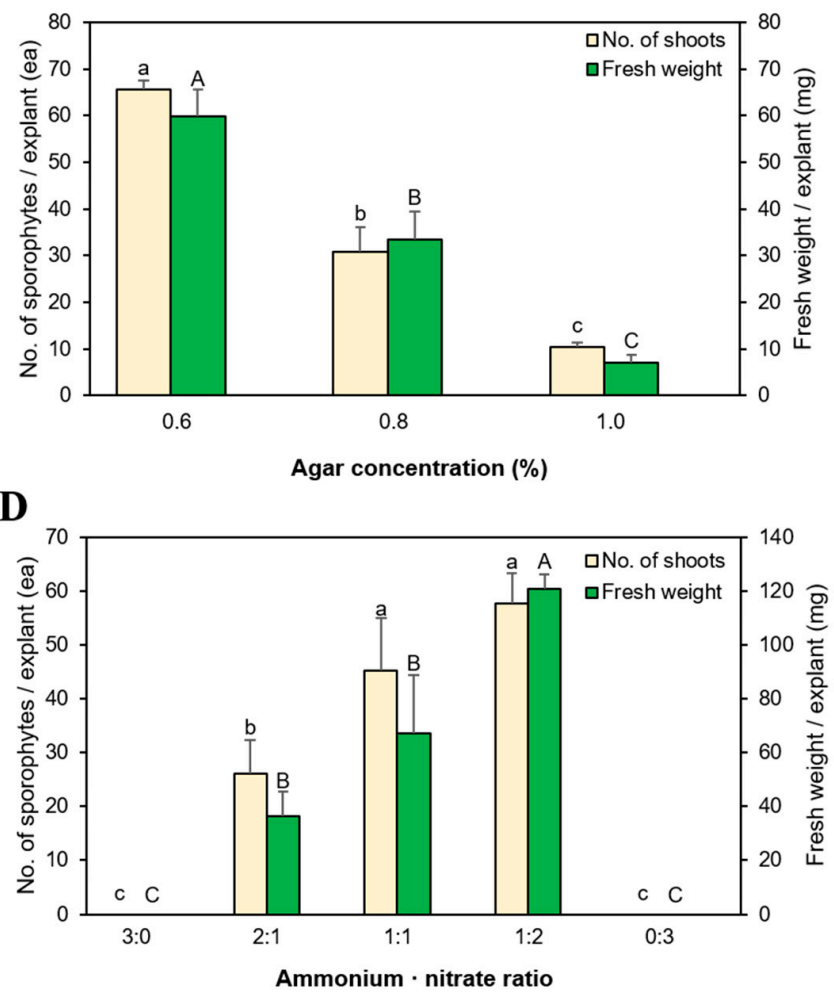

Figure 2. Effect of medium components on S. tamariscina (P.Beauv.) Spring growth and sporophyte regeneration. Results according to various (A) sucrose, (B) agar, and (C) total nitrogen concentrations, as well as (D) nitrogen ratios, following 12-week in vitro culture. Small letters and capital letters above the bars indicate the statistical difference of a number of sporophytes and fresh weight, respectively, by Duncan's multiple range test at $p<0.05$.

\subsection{Acclimation}

S. tamariscina transplanted into soil successfully adapted to a humidity-controlled environment. Additionally, new sporophytes formed from the existing sporophytes during rooting exhibited normal growth (Figure 3E. Furthermore, soil-adapted S. tamariscina slowly lowered the humidity of the plastic box in culture and successfully acclimated to the greenhouse.
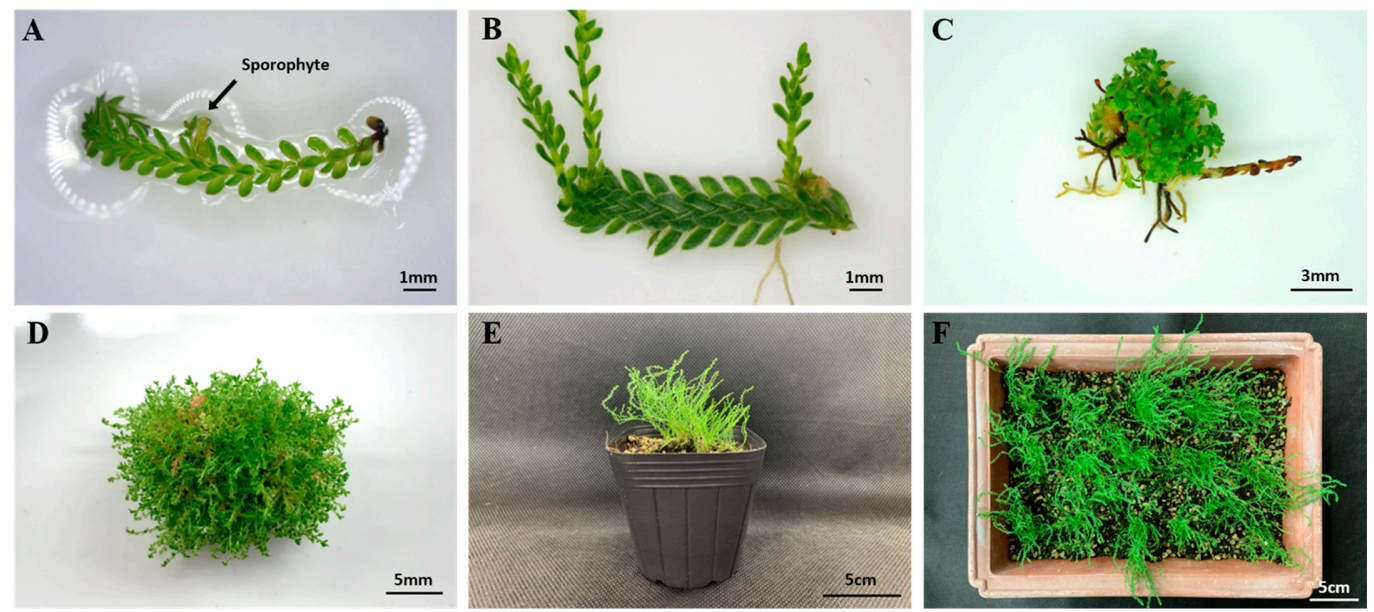

Figure 3. Propagation and acclimation of S. tamariscina (P.Beauv.) Spring regenerated from the shoot tip of a sporophyte. (A) A $12 \mathrm{~mm}$ shoot tip. (B) Sporophytes regenerated in various parts of the shoot tip. (C) Explant after an 8-week culture with large amounts of sporophytes. (D) Sporophytes formed from explants at week 12 of culture. (E) Sporophyte acclimated for 12 weeks under a controlled environment. (F) S. tamariscina adaption in greenhouse. 


\section{Discussion}

In this study, we demonstrated successful in vitro culturing of S. tamariscina shoot tips, resulting in mass propagation of sporophytes under optimized conditions for growth and propagation. Ferns can multiply by using various sites for sporophyte and gametophyte propagation [27-31]. In the present study, we showed that S. tamariscina was able to proliferate using shoots formed in vitro, and that multiple shoots were formed from shoot tips to allow the formation of numerous sporophytes (Figure 3). Additionally, a longer explant length resulted in a higher number of sporophyte-regeneration sites, which effectively increased the sporophyte reproduction rate (Figure 3B). Jha [32] produced plants in medium containing plant-growth regulators for the propagation of Selaginella microphylla, whereas in the present study, we showed that S. tamariscina regeneration was possible in medium without plant-growth regulators. In addition, sporophyte explants from Selaginella martensii do not form new sporophytes; instead, they merely grow [21]. In contrast, $S$. tamariscina sporophyte explants regenerate several sporophytes and thus ensure effective propagation.

The choice of nutrient medium is important for successful plant culture [33], with the components of the medium having various effects on plant growth and propagation [34-37]. MS medium is mainly used for the culture of ferns and comprises different concentrations of components suitable for growth $[35,38]$. In the present study, we confirmed that altering the concentrations of MS components affected S. tamariscina growth and propagation, with optimal results obtained at $1 / 4 \mathrm{MS}$. This medium is thought to be low in nutritional content and based on native S. tamariscina growth among rocks [39]. Shin and Lee [40] reported that the epiphytic fern Pyrrosia linearifolia shows optimum growth in 1/8MS medium, whereas we found that $S$. tamariscina did not grow well at concentrations below $1 / 8 \mathrm{MS}$ because of a lack of inorganic nutrients necessary for growth.

Plants undergoing in vitro culture require a carbon source for growth [41]. Sucrose was used as an energy source for plants in early in vitro environments, where photosynthesis was limited [42]. The carbon source varies according to plant; therefore, it is important to provide both the appropriate type and concentration of compound [43,44]. In the present study, we identified the optimal sucrose concentration required for $S$. tamariscina growth, although we also observed sporophyte regeneration in medium without sucrose. This suggests that sucrose might not be essential for sporophyte regeneration; however, the addition of sucrose at the proper concentration appears to promote sporophyte formation.

Similarly, nitrogen is an essential component of plant growth, with its effect varying from species to species [45-48]. In the present study, we evaluated the effects of nitrogen type and ratio on propagation and growth. Previous studies reported that Dryopteris varia shows the highest sporophyte formation at $30 \mathrm{mM}$ nitrogen, whereas Phyllitis scolopendrium displays optimal sporophyte regeneration at nitrogen concentrations lower than $30 \mathrm{mM}[36,49] . \mathrm{NH}_{4}{ }^{+}$promotes germination and gametophyte growth in Ophioglossum and Botrychium [45,48], whereas it causes rapid gametophyte aging and necrosis in Botrychium jenmanii [46]. By contrast, Osmunda japonica shows the maximum gametophyte growth in the presence of $\mathrm{NO}_{3}{ }^{-}$alone, and Dyropteris varia displays excellent growth at increased ratios of $\mathrm{NO}_{3}{ }^{-}[37,50]$. In the present study, we found that $S$. tamariscina growth is promoted at a relatively low nitrogen concentration $(15 \mathrm{mM})$, whereas explant necrosis is observed upon treatment with $\mathrm{NH}_{4}{ }^{+}$or $\mathrm{NO}_{3}{ }^{-}$alone, confirming that $S$. tamariscina requires two types of nitrogen for growth.

Agar is used to support explants during in vitro culture, and when present in appropriate concentrations, it can promote plant growth [51,52]. In the present study, we found that low agar concentration is the most appropriate for the better propagation and growth of S. tamariscina. In general, stiffness increases as the concentration of agar increases. In addition, high gel stiffness affects root elongation and extension [53]. The formation of sporophytes was relatively lower at higher agar concentrations. This could be caused by low moisture utilization efficiency due to high agar concentration [54]. In contrast, 
hyperhydricity can occur when the concentration of agar is too low [54-56]. However, no hyperhydricity in S. tamariscina was observed in our study.

Plants undergoing in vitro culture grow in a controlled environment and are sensitive to alterations in environmental conditions. Therefore, acclimation of these plants is necessary to allow their adaption to external environments [57], without which the plants will be damaged and will subsequently be unable to adapt to rapid environmental changes [58]. Plant acclimation is influenced by a variety of factors [59], with rooting being of particular importance. Here, we found that in vitro growth of $S$. tamariscina roots was relatively slow compared to that of its aboveground parts, resulting in a low acclimation-success rate. Therefore, we induced plant rooting by transplanting into soil under a controlled environment prior to acclimation, and this process resulted in rapid growth. This procedure promoted more effective $S$. tamariscina growth relative to that in the in vitro environment and allowed successful acclimation in the greenhouse.

\section{Conclusions}

In this study, we successfully mass propagated S. tamariscina by adjusting various medium components in vitro. The present results indicate that the use of the shoot tip for explanting can yield numerous sporophytes and appropriate concentrations of various components of the medium contribute to faster and larger growth of the sporophytes. This experiment found optimal conditions by adjusting each component added to the medium.

In addition, the study of the interaction between components with these optimal conditions is thought to have additional results in the regeneration of S. tamariscina. Our proliferation method can be applied to the cultivation of S. tamariscina-a medicinal plant with important value - and can be used for additional studies to increase the secondary metabolites. In our study, the proliferation method of S. tamariscina using sporophytes proved the capability of forming a huge number of sporophytes. Therefore, the stable supply of plants using this proliferation method would protect the plants in nature from indiscriminate collection. Additionally, this method could potentially be applied to the Selaginella species, which has similar problems, as a model for securing the quantity of plants and proliferation.

Author Contributions: Conceptualization, K.P. and C.H.L.; Methodology, K.P. and C.H.L.; Formal Analysis, K.P. and B.K.J.; Resources, C.H.L.; Data Curation, H.M.L. and J.S.C.; Writing-Original Draft Preparation, K.P.; Writing-Review and Editing, B.K.J., C.H.L., and J.S.C.; Project Administration, C.H.L.; Funding Acquisition, C.H.L. All authors have read and agreed to the published version of the manuscript.

Funding: This research received no external funding.

Institutional Review Board Statement: Not applicable.

Informed Consent Statement: Not applicable.

Data Availability Statement: Data sharing not applicable.

Acknowledgments: This work was financially supported by the Research Year of Chungbuk National University in 2019.

Conflicts of Interest: The authors declare no conflict of interest.

\section{References}

1. Ma, S.C.; But, P.P.H.; Ooi, V.E.C.; He, Y.H.; Lee, S.H.S.; Lee, S.F.; Lin, R.C. Antiviral amentoflavone from Selaginella sinensis. Biol. Pharm. Bull. 2001, 24, 311-312. [CrossRef]

2. Su, Y.; Sun, C.M.; Chuang, H.H.; Chang, P.T. Studies on the cytotoxic mechanisms of ginkgetin in a human ovarian adenocarcinoma cell line. Naunyn Schmiedebergs Arch. Pharm. 2000, 362, 82-90. [CrossRef]

3. Cao, Y.; Tan, N.H.; Chen, J.J.; Zeng, G.Z.; Ma, Y.B.; Wu, Y.P.; Yan, H.; Yang, J.; Lu, L.F.; Wang, Q. Bioactive flavones and biflavones from Selaginella moellendorffii Hieron. Fitoterapia 2010, 81, 253-258. [CrossRef]

4. Silva, G.L.; Chai, H.; Gupta, M.P.; Farnsworth, N.R.; Cordell, G.A.; Pezzuto, J.M.; Beecher, C.W.; Kinghorn, A.D. Cytotoxic biflavonoids from Selaginella willdenowii. Phytochemistry 1995, 40, 129-134. [CrossRef] 
5. Lin, L.C.; Kuo, Y.C.; Chou, C.J. Cytotoxic biflavonoids from Selaginella delicatula. J. Nat. Prod. 2000, 63, 627-630. [CrossRef]

6. Chao, L.R.; Seguin, E.; Tillequin, F.O.; Koch, M. New alkaloid glycosides from Selaginella doederleinii. J. Nat. Prod. 1987, 50, 422-426. [CrossRef]

7. Lin, R.C.; Skaltsounis, A.L.; Seguin, E.; Tillequin, F.; Koch, M. Phenolic constituents of Selaginella doederleinii. Planta Med. 1994, 60, 168-170. [CrossRef] [PubMed]

8. Lee, H.S.; Oh, W.K.; Kim, B.Y.; Ahn, S.C.; Kang, D.O.; Shin, D.I.; Kim, J.; Mheen, T.I.; Ahn, J.S. Inhibition of phospholipase C $\gamma 1$ activity by amentoflavone isolated from Selaginella tamariscina. Planta Med. 1996, 62, 293-296. [CrossRef] [PubMed]

9. Sun, C.M.; Syu, W.J.; Huang, Y.T.; Chen, C.C.; Ou, J.C. Selective cytotoxicity of ginkgetin from Selaginella moellendorffii. J. Nat. Prod. 1997, 60, 382-384. [CrossRef] [PubMed]

10. Jung, H.J.; Sung, W.S.; Yeo, S.H.; Kim, H.S.; Lee, I.S.; Woo, E.R.; Lee, D.G. Antifungal effect of amentoflavone derived from Selaginella tamariscina. Arch. Pharm. Res. 2006, 9, 746-751. [CrossRef] [PubMed]

11. Swamy, R.C.; Kunert, O.; Schuhly, W.; Bucar, F.; Ferreira, D.; Rani, V.S.; Kumar, B.R.; Rao, A.V.N.A. Structurally unique biflavonoids from Selaginella chrysocaulos and Selaginella bryopteris. Chem. Biodivers. 2006, 3, 405-413. [CrossRef]

12. Lee, C.W.; Choi, H.J.; Kim, H.S.; Kim, D.H.; Chang, I.S.; Moon, H.T.; Lee, S.Y.; Oh, W.K.; Woo, E.R. Biflavonoids isolated from Selaginella tamariscina regulate the expression of matrix metalloproteinase in human skin fibroblasts. Bioorg. Med. Chem. 2008, 16, 732-738. [CrossRef]

13. Wang, Y.H.; Long, C.L.; Yang, F.M.; Wang, X.; Sun, Q.Y.; Wang, H.S.; Shi, Y.N.; Tang, G.H. Pyrrolidinoindoline alkaloids from Selaginella moellendorfii. J. Nat. Prod. 2009, 72, 1151-1154. [CrossRef]

14. Zheng, X.K.; Li, Y.J.; Zhang, L.; Feng, W.S.; Zhang, X. Antihyperglycemic activity of Selaginella tamariscina (Beauv.) Spring. J. Ethnopharmacol. 2011, 133, 531-537. [CrossRef]

15. Ahn, D.K. Illustrated Book of Korean Medicinal Herbs; Kyohaksa: Seoul, Korea, 1998.

16. Shin, D.I.; Kim, J.W. Flavonoid constituents of Selaginella tamariscina. Korean J. Pharmacogn. 1991, 22, $207-210$.

17. Lee, I.R.; Song, J.Y.; Lee, Y.S. Cytotoxicity of folkloric medicine in murine and human cancer cells. Korean J. Pharmacogn. 1992, 23, 132-134.

18. Bae, K.H. The Medicinal Plants of Korea; Kyohaksa: Seoul, Korea, 2000.

19. Yang, J.W.; Pokharel, Y.R.; Kim, M.R.; Woo, E.R.; Choi, H.K.; Kang, K.W. Inhibition of inducible nitric oxide synthase by sumaflavone isolated from Selaginella tamariscina. J. Ethnopharmacol. 2006, 105, 107-113. [CrossRef] [PubMed]

20. Fernández, H.; Bertrand, A.M.; Sánchez-Tamés, R. In vitro regeneration of Asplenium nidus L. from gametophytic and sporophytic tissue. Sci. Hort. 1993, 56, 71-77. [CrossRef]

21. Park, K.; Jang, B.K.; Lee, H.M.; Cho, J.S.; Lee, C.H. An efficient method for in vitro shoot-tip culture and sporophyte production using Selaginella martensii Spring sporophyte. Plants 2020, 9, 235. [CrossRef] [PubMed]

22. Barnicoat, H.; Cripps, R.; Kendon, J.; Sarasan, V. Conservation in vitro of rare and threatened ferns-case studies of biodiversity hotspot and island species. Cell. Dev. Biol. Plant. 2011, 47, 37-45. [CrossRef]

23. Lee, J.; Kim, M.; Jeong, S.E.; Park, H.Y.; Jeon, C.O.; Park, W. Amentoflavone, a novel cyanobacterial killing agent from Selaginella tamariscina. J. Hazard. Mater. 2020, 384, 121312. [CrossRef] [PubMed]

24. Woo, S.; Kang, K.B.; Kim, J.; Sung, S.H. Molecular networking reveals the chemical diversity of selaginellin derivatives, natural phosphodiesterase-4 inhibitors from Selaginella tamariscina. J. Nat. Prod. 2019, 82, 1820-1830. [CrossRef] [PubMed]

25. Jiang, Y.; Wang, S.; Yu, M.; Wu, D.; Lei, J.; Li, W.; He, Y.; Gang, W. Ultrasonic-Assisted Ionic Liquid Extraction of Two Biflavonoids from Selaginella tamariscina. ACS Omega 2020, 51, 33113-33124. [CrossRef] [PubMed]

26. Murashige, T.; Skoog, F. A revised medium for rapid growth and bioassays with tobacco tissue cultures. Physiol. Plant. 1962, 15, 473-497. [CrossRef]

27. Hicks, G.; Aderkas, P. A tissue culture of the ostrich fern Matteuccia struthiopteris L. Todaro. Plant Cell Tissue Org. Cult. 1986, 5, 199-204. [CrossRef]

28. Higuchi, H.; Amaki, W.; Suzuki, S. In vitro propagation of Nephrolepis cordiflora. Sci. Hort. 1987, 32, 105-113. [CrossRef]

29. Fernández, H.; Bertrand, A.M.; Sánchez-Tamés, R. Plantlet regeneration in Asplenium nidus L. and Pteris ensiformis L. by homogenisation of BA treated rhizomes. Sci. Hort. 1997, 68, 243-247. [CrossRef]

30. Ambrožič-Dolinšek, J.; Camloh, M.; Bohanec, B.; Žel, J. Apospory in leaf culture of Staghorn fern (Platycerium bifurcatum). Plant Cell Rep. 2002, 20, 791-796. [CrossRef]

31. Mikuła, A.; Pożoga, M.; Tomiczak, K.; Rybczyński, J.J. Somatic embryogenesis in ferns: A new experimental system. Plant Cell Rep. 2015, 34, 783-794. [CrossRef]

32. Jha, T.B.; Mukherjee, S.; Basak, A.; Adhikari, J. In vitro morphogenesis in Selaginella microphylla (Kunth.) Spring. Plant Biotechnol. Rep. 2013, 7, 239-245. [CrossRef]

33. Gamborg, O.L.; Murashige, T.; Thorpe, T.A.; Vasil, I.K. Plant tissue culture media. In Vitro 1976, 12, 473-478. [CrossRef]

34. Morini, S. In vitro culture of Osmunda regalis fern. J. Hortic. Sci. Biotechnol. 2000, 75, 12-18. [CrossRef]

35. Fernández, H.; Revilla, M.A. In vitro culture of ornamental ferns. Plant Cell Tissue Organ Cult. 2003, 73, 1-13. [CrossRef]

36. Jung, J.A.; Lee, C.H. Factors affected on plant regeneration of Phyllitis scolopendrium (L.) Newman in vitro. Korean J. Plant. Res. 2006, 19, 365-373.

37. Shin, S.L.; Lee, C.H. In vitro medium composition and culture method affecting mass propagation of Osmunda japonica Thunb. prothalli. Korean J. Hortic. Sci. 2009, 27, 299-304. 
38. Rybczyński, J.; Mikuła, A. Tree ferns biotechnology: From spores to sporophytes. In Working with Ferns: Issues and Applications, 1st ed.; Fernández, H., Kumar, A., Revilla, A., Eds.; Springer: Berlin/Heidelberg, Germany, 2010.

39. Lee, C.S.; Lee, K.H. Pteridophytes of Korea: Lycophytes \& Ferns, 2nd ed.; Geobook: Seoul, Korea, 2018.

40. Shin, S.L.; Lee, C.H. Optimal culture conditions for masspropagation of gametophyte and sporophyte of Pyrrosia linearifolia by tissue culture. Flower Res. J. 2010, 18, 179-185.

41. George, E.F. Plant. Propagation by Tissue Culture. Part. 1. The Technology, 2nd ed.; Exegetics Ltd.: Edington, UK, 1993.

42. Dyer, A.F. The Experimental Biology of Ferns; Academic Press: London, UK, 1979.

43. Fernández, H.; Bertrand, A.M.; Sánchez-Tamés, R. Biological and nutritional aspects involved in fern multiplication. Plant Cell Tissue Organ. Cult. 1999, 56, 211-214. [CrossRef]

44. Paiva Neto, V.B.; Otoni, W.C. Carbon sources and their osmotic potential in plant tissue culture: Does it matter? Sci. Hortic. 2003, 97, 193-202. [CrossRef]

45. Melan, M.A.; Whittier, D.P. Effects of inorganic nitrogen sources on spore germination and gametophyte growth in Botrychium dissectum. Plant Cell Environ. 1990, 13, 477-482. [CrossRef]

46. Whittier, D.P.; Thomas, R.D. Gametophytes and young sporophytes of Botrychium jenmanii in axenic culture. Int. J. Plant. Sci. 1993, 154, 68-74. [CrossRef]

47. Fernández, H.; Bertrand, A.M.; Sánchez-Tamés, R. Gemmation in Osmunda regalis L. gametophyte cultured in vitro. Plant Cell Rep. 1997, 16, 358-362. [CrossRef]

48. Whittier, D.P. Rapid gametophyte maturation in Ophioglossum crotalophoroides. Am. Fern J. 2003, 93, 137-145. [CrossRef]

49. Jung, J.A.; Lee, C.H. Mass propagation of Dryopteris varia (L.) O. Kuntze by sporophyte culture. Kor. Soc. Floricult. Sci. 2006, $14,25-34$.

50. Jung, J.A.; Lee, C.H. Several factors affecting on in vitro culture of prothallus and ex vitro sporophyte formation from prothallus of Dyropteris varia (L.) O. Kuntze. Korean J. Plant. Res. 2006, 19, 252-258.

51. Pevalek-Kozlina, B. Effects of sucrose and agar concentration, and medium $\mathrm{pH}$ on staghorn fern [Platycerium bifurcatum (Cav.) C.Chr.] shoot multiplication. Hortic. Sci. 1996, 28, 18-20.

52. Fernández, H.; Bertrand, A.M.; Feito, I.; Sánchez-Tamés, R. Gametophyte culture in vitro and antheridiogen activity in Blechnum spicant. Plant Cell Tissue Org. Cult. 1997, 50, 71-74. [CrossRef]

53. Yan, J.; Wang, B.; Zhou, Y.; Hao, S. Resistance from agar medium impacts the helical growth of Arabidopsis primary roots. J. Mech. Behav. Biomed. 2018, 85, 43-50. [CrossRef]

54. Smith, M.A.L.; Spomer, L.A. Vessels, gels, liquid media, and support systems. In Automation and Environmental Control in Plant Tissue Culture; Aitken-Christie, J., Kozai, T., Smith, M.A.L., Eds.; Springer: Dordrecht, The Netherlands, 2013.

55. Debergh, P. Effects of agar brand and concentration on the tissue culture medium. Physiol. Plant. 1983, 59, 270-276. [CrossRef]

56. Debergh, P.; Aitken-Christie, J.; Cohen, D.; Grout, B.; Von Arnold, S.; Zimmerman, R.; Ziv, M. Reconsideration of the term 'vitrification' as used in micropropagation. Plant Cell Tissue Organ. Cult. 1992, 30, 135-140. [CrossRef]

57. Hazarika, B.N. Acclimatization of tissue-cultured plants. Curr. Sci. 2003, 85, 1704-1712.

58. Pospíšilová, J.; Tichá, I.; Kadleček, P.; Haisel, D.; Plzáková, S. Acclimatization of micropropagated plants to ex vitro conditions. Biol. Plantarum 1999, 42, 481-497. [CrossRef]

59. Preece, J.E.; Sutter, E.G. Acclimatization of micropropagated plants to the greenhouse and field. In Micropropagation. Technology and Application; Debergh, P.C., Zimmerman, R.H., Eds.; Springer: Dordrecht, The Netherlands, 1991. 